\title{
Geodiversity mapping of the Bakony-Balaton UNESCO Global Geopark, Hungary
}

\author{
Márton Pál ${ }^{\mathrm{a}, \mathrm{b}, *}$, Gáspár Albert ${ }^{\mathrm{b}}$ \\ ${ }^{a}$ ELTE Eötvös Loránd University, Doctoral School of Earth Sciences, marchello@map.elte.hu \\ ${ }^{b}$ ELTE Eötvös Loránd University, Faculty of Informatics, Institute of Cartography and Geoinformatics, albert@ludens.elte.hu \\ * Corresponding author
}

\begin{abstract}
Geodiversity is the natural range of elements in the physical environment. The relationships, properties, and systems of geoscientific features have an impact not only on the natural world but also on cultural and societal aspects of life. Geodiversity can be considered as a quantitative variable that is unevenly distributed all over the world. This spatial variability helps to locate areas with a high degree of geodiversity. These areas can be the basis of further nature protection and geotourism purposes: high geodiversity usually means higher scientific/cultural/ecological values in an area. We present a GIS-based workflow in which we collect, evaluate, and visualize geoscientific variables to provide information on the geodiversity of the Bakony-Balaton UNESCO Global Geopark in Hungary. By using mainly freely accessible data and an open-source GIS environment, we aim to develop a method that can be applied in many areas of the world. The evaluation is built up by the determination of five sub-indices per unit area, which are related to the elements of geodiversity: geology, relief, hydrology, soil, palaeontology, and mineralogy. The geodiversity index is the sum of the sub-indices. The current tourism potential is mainly found in the high geodiversity regions: the Balaton Uplands, the Tapolca Basin, the Káli Basin, and the Bakony Mountains. The results show that the current geopark infrastructure is in accordance with the geodiversity, but it took several years to reach this state. However, new geoparks are established every year and their infrastructure is yet to be planned. The method we apply helps in this process by using open-source data in the assessment and provides a workflow in areas that have not been evaluated before.
\end{abstract}

Keywords: geodiversity, GIS analysis, visualization, geosciences

\section{Introduction}

The term 'geodiversity' is very complex, as examining, assessing the elements of the geoscientific environment objectively is a hard task. After defining 'biodiversity' 'the variability among living organisms from all sources including, inter alia, terrestrial, marine, and other aquatic ecosystems and the ecological complexes of which they are part; this includes diversity within species, between species and of ecosystems' (Minelli \& Bonato 2012) 'geodiversity' also started to develop. Natural heritage is an important renewable resource and includes all biotic and abiotic components that support our existence (Gray 2004). The complexity of our earth scientific surroundings can be evaluated and examined using the toolset of geodiversity that holds many further opportunities. These aspects urge the geoscientific community to map geodiversity: the proper utilization of physical environmental features has a great effect on sustainable development through many of the 17 SDGs (Sustainable Development Goals) adopted by the UN states in 2015 .

According to the developing definition, geodiversity is 'the natural range (diversity) of geological (rocks, minerals, fossils), geomorphological (landform, processes) and soil features. It includes their assemblages, relationships, properties, interpretation, and systems' (Gray 2004). As it is recognised most recently, geodiversity is the backbone of geoheritage and geoconservation. It also shows strong connections to modern society as it is the base of and geotourism development too (Gray 2008, Gray 2018).

Practically, geodiversity can be considered as the quantification of the earth scientific properties of a certain area. It is a quantitative thematic variable that is continuous all over the world: this is the conceptual basis for mapping it. During the assessment or evaluation process usually, an index score is calculated using various cartographic and spatial database materials (e.g., Kozłowski 2004; Serrano \& Ruiz-Flaño 2007; Pereira et al. 2013; De Paula Silva et al. 2015).

Our paper aims to present a GIS-based geodiversity assessment workflow (mostly based on Pereira et al. 2013) and to visualise our results of the Bakony-Balaton UNESCO Global Geopark. Geological, geomorphological, pedological, hydrological, mineralogical, and palaeontological elements of the natural environment were examined. The use of FOSS (Free and Open-Source Software) analytical solutions and mostly open-source base data offers a possibility for areas where geodiversity has not been assessed before. 


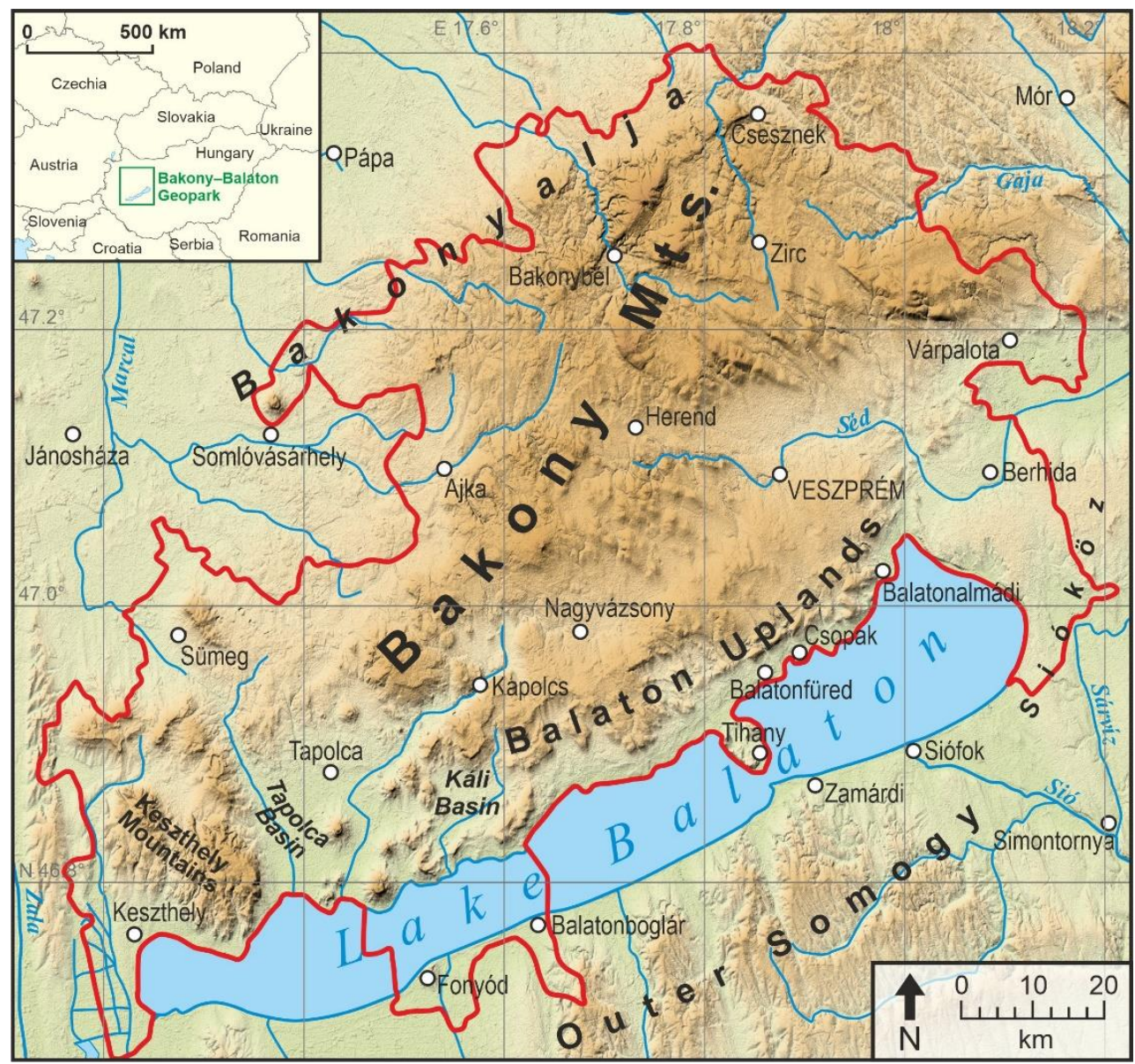

Figure 1. The area of the Bakony-Balaton UNESCO Global Geopark (red border)

\section{Our sample area: the Bakony-Balaton UNESCO Global Geopark}

The $3244 \mathrm{~km}^{2}$ area of the Geopark (Fig. 1) encompasses 151 settlements and operates under the umbrella of the Balaton Uplands National Park. Besides the area of the National Park, many other nature protection areas and natural heritage sites can be found here. As four major landscapes (Transdanubian Range, Transdanubian Hills, Kisalföld and Alföld) of Hungary meet within the borders of the Geopark, it is characterised by great geological, morphological, climatological, hydrological, and biological diversity (Budai et al. 2021).

Most of the Geopark is built up by sedimentary rocks, but there are important volcanic areas too. The massif of the Bakony moved to its current place in millions of years. The oldest geological formations are related to it: they are present in its edges, near Lake Balaton (e.g., the siliceous shales at Alsóörs or the Litér Metabasalt). These 500million-year-old rocks were followed by sedimentation in the Permian (Balatonfelvidék Sandstone). The Triassic was mostly characterised by the shallow flood of the Thetys Sea. Shallow water marl, sandstone and dolomite were formed in the Early Triassic. 245 million years ago, the sedimentary basin was broken: the anaerobic environment of the lower parts gave place for the formation of the bituminous Felsőörs Limestone. The remnants of undersea volcanism can also be traced (Nemesvámos Limestone). Calm sedimentation (Füred Limestone - an important building rock, Veszprém Marl and Dachstein Limestone) took place in the Late Triassic: the main massif of the Bakony was formed. In the Jurassic, sea carbonates sedimented with rich fossil fauna (e.g., Tüzkövesárki Limestone, Eplény Limestone). By the end of the Cretaceous, most of the area was elevated. Karstic formations and bauxite (Halimba, Gánt, Darvastó) were formed in the tropical climate of the Late Cretaceous and Early Cenozoic. The fluvial sediments of the era are exceptionally rich in fossils (e.g., the dinosaurs and other vertebrates of Iharkút, Ösi 2004). The fluvial and shallow sea sedimentation of the Miocene was followed by the lifting of the Bakony. Phreatomagmatic volcanism took place because of the water-magma interaction 8 million years ago (Kab-hegy, Tihany Peninsula, Badacsony). The formation of some important geosites is related to post volcanic activities (Golden House - Tihany, Lóczy Cave Balatonfüred). In the Pleistocene erosion processes worked in the area: the witness mountains of the Balaton Uplands were formed. The first traces of Lake Balaton can be found 15000 years ago. Due to the increasing amount of precipitation, many small lakes were united approx. 5000 years ago (Budai et al. 1999, Budai et al. 2021). 
The ecological heritage is also diverse, as the Geopark is on the border of the continental, Atlantic and Mediterranean climate zones. The base stone, soils and relief also influence the flora and the fauna. The wetlands of the Tihany Peninsula and the Kális Basin (Lake Kornyi), the unique oak woods of the southern part of the Bakony and the Balaton Uplands, cliff habitats and the Lake Balaton give a home to a great variety of protected plants and animals (Budai et al. 2021).

The geological and biological heritage of the area shows a strong connection to cultural heritage. The mining of building stones and agricultural activity started thousands of years ago. Buildings, vineyards, and traditional professions are also important attractions of the area with all the other tourism infrastructure built around the shores of Lake Balaton (Bakony-Balaton Geopark 2020, Budai et al. 2021).

\section{Methodology and data}

The assessment process of this paper is mainly based on Pereira et al. (2013), but some modifications were made in base data sources and processing in order to increase the amount of open-source material. The evaluation is built up by the determination of various sub-indices that relate to geodiversity elements: geology, geomorphology (relief and hydrology), soils, palaeontology, and mineralogy (precious and building stones, mineral waters and energy sources). The overall geodiversity index is the sum of these sub-indices.

Free and open-source software - QGIS 3.16, GRASS GIS 7.8.4 and SAGA 2.3.2 - were used during the assessment to ensure reproducibility. The spatial functions and processing tools of these were suitable for all of our base data.

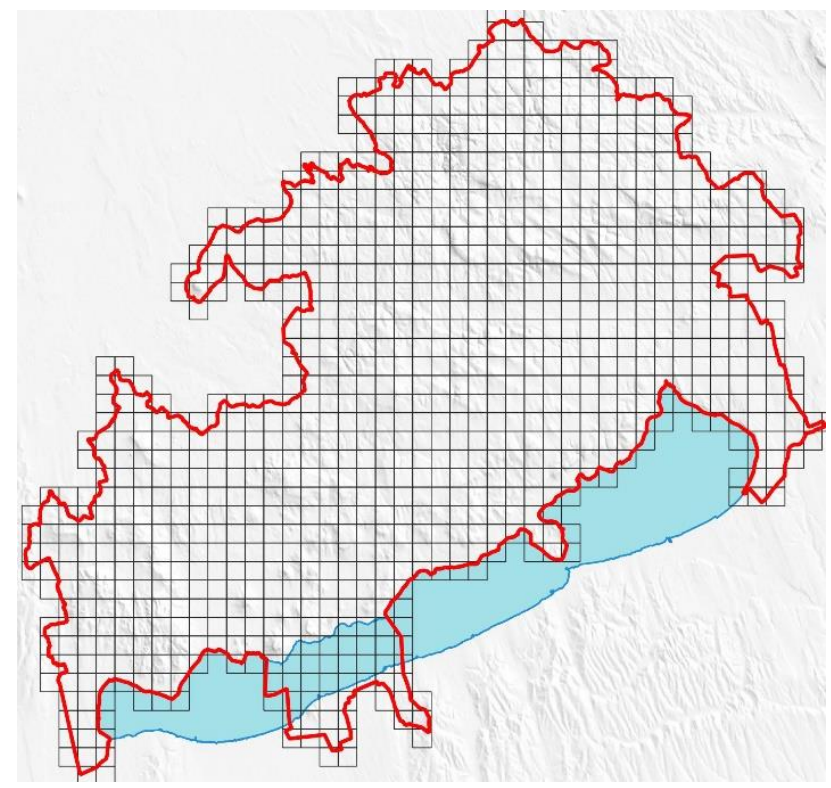

Figure 2 . The $2 * 2 \mathrm{~km}$ grid layer is placed over the Geopark. 949 cells were determined, and all sub-indices were calculated for each of them

The $3244 \mathrm{~km}^{2}$ area of the Geopark (Fig. 1) was mapped with the help of a $2 * 2 \mathrm{~km}$ raster grid (QGIS 'Create grid' tool, Fig. 2). Each square is considered as a homogenous unit and every sub-index was determined for each cell. The reason for applying this raster visualisation was that while an interpolated, continuous map may distort the spatial pattern of geodiversity index values, the homogenous grid preserves the original layout of the data. The resolution of the grid depends on two factors: the size of the sample area and the scale of the available base data. The $2 * 2 \mathrm{~km}$ distribution proved to be well-applicable when examining these two aspects.

After the creation of the grid, we focused on the analysis of the sub-indices. The methodology of index calculation often has relations to other sub-indices, but different data sources were used in most cases. Examples of calculations on base data can be seen in Fig. 3 .

The 1:100 000-scale vector geological map (Gyalog \& Síkhegyi 2005) of Hungary was processed with QGIS to produce the geological sub-index (Fig. 3a) of each cell. After creating a raster version of the dataset (QGISGDAL, 'Rasterize - vector to raster') every distinct formation was counted in the cells (with the help of the different raster values - 'Zonal Statistics' tool's 'Variety' attribute gives the correct number). These values were considered as the geological diversity subindex of each square. The minimum value was 0 (over Lake Balaton) and the maximum was 21 .

The pedological subindex (Fig. 3b) was created similarly (with rasterization and applying 'Zonal Statistics') but with a different dataset: the 'AGROTOPO 100' 1:100 000scale soil map of Hungary (ATK TAKI 2020). The minimum value was 0 and the maximum was 5 . We have tried to apply open data for this purpose (Panagos et al. 2011), but it did not give proper results due to small scale. The geomorphological sub-index is built up by two parts: relief (Fig. 3c) and hydrology (Fig. 3d). The calculation of the relief index differs from previous studies, as we used DEMs and the theory of geomorphons (Jasiewicz \& Stepinski 2013). We used a corrected version of the SRTM 3 data: the MERIT DEM digital elevation model (Yamazaki et al. 2017). The corresponding data were loaded in GRASS GIS, where the 'r.geomorphon' tool produces the geomorphon map (with correct parametrisation that depends on the desired complexity and the resolution of the base dataset). This map is a quasilandform map presenting 10 different landform types. As there are hardly good quality and proper scaled geomorphological maps in many countries of the world, this open-source solution may give good and realistic results. The distinct landform types were calculated in each cell using 'Zonal Statistics' and the relief index was produced. The minimum value was 0 and the maximum was 10 .

The determination of the hydrological index was also achieved by using open-source data. We also chose MERIT DEM as the base data that we processed with the hydrological tools of SAGA GIS. After creating a depressionless layer with the 'Fill sinks' tool, a 'Flow direction' raster was made to enhance the results. The 'Channel network' tool extracts the valley lines (in raster 
format) of the DEM, and it can be converted to a vector dataset. However, natural processes and conditions modify this pattern: there is no watercourse in every valley. To filter these mistakes, OpenStreetMap and large-scale topographic maps were used. Fortunately, the manual rectification required moderate work - especially limestone and karstic areas needed modification. The resulting vector layer can be categorised using SAGA's 'Strahler order' tool: this groups watercourses according to hierarchical order (Strahler 1957). The value of the hydrological index in each cell is the highest hierarchical level divided by 2 , rounded up to the nearest integer (e.g., $5 / 2$ rounded to 3 ). The minimum value was 0 and the maximum was 3 .
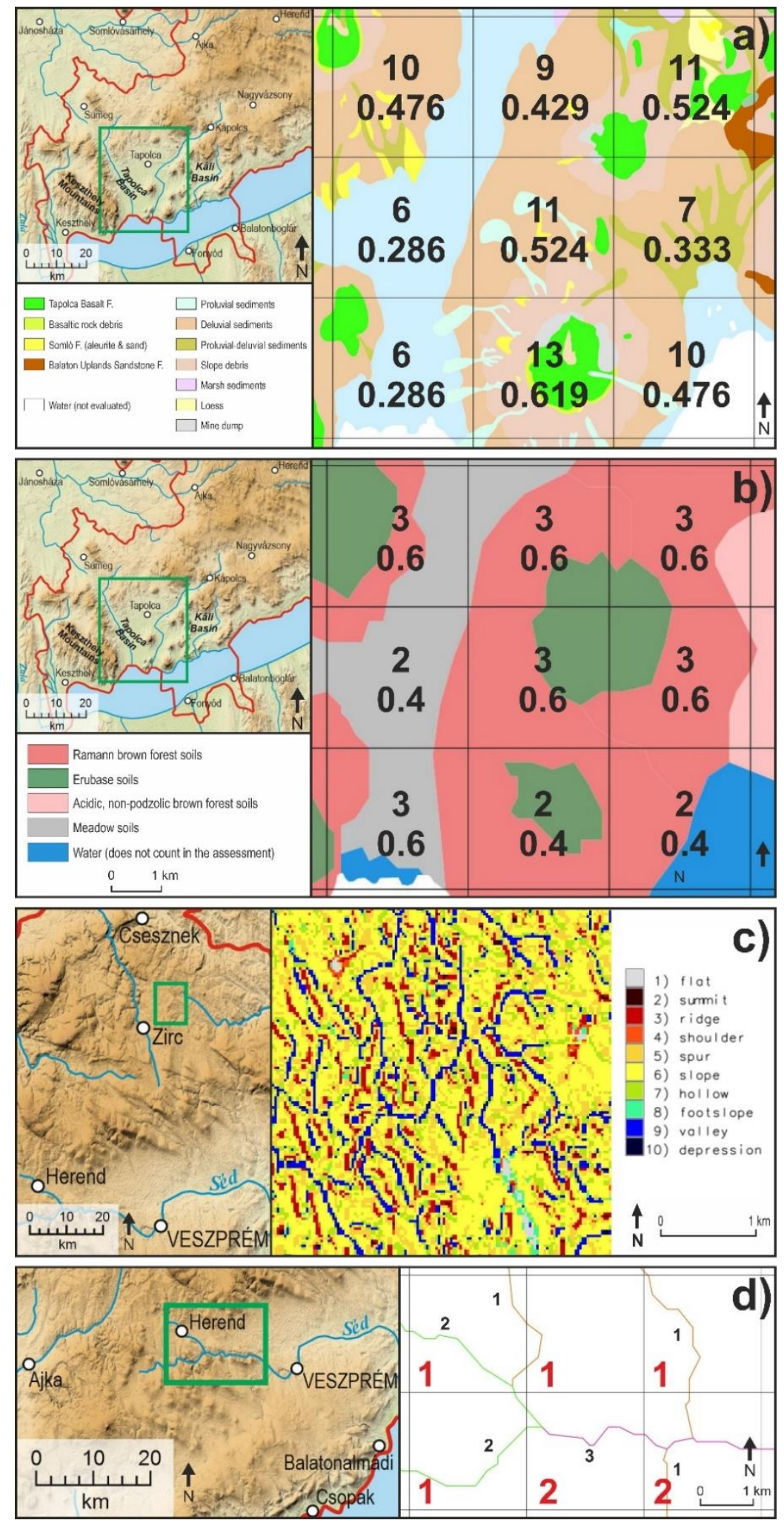

Figure 3. Extracts from the sample area with calculated sub-indices: a) geological, b) pedological, c) relief, d) hydrological 
The determination of palaeontological and mineralogical sub-indices followed the same workflow. Unfortunately, there are no open-source middle- or large-scale maps available in these topics, so we decided to examine the geological formation descriptions (Császár 1997, Gyalog 1996, Gyalog 2005). In each cell, every different fossil in case of the palaeontological sub-index and mineral features (precious stones, metallic minerals, industrial minerals, geological energy sources and mineral waters) in case of the mineralogical sub-index were counted producing the last two thematic sub-values. The minimum of both values was 0 , while the maximum of the mineral index was 5 and the maximum of the palaeontological index was 9 .

\section{Results}

By summarizing subindices in each cell, the geodiversity index was produced. Five categories were created for visualisation by using the 'Natural Breaks' method (Jenks 1967). The thematic variables and the overall geodiversity index can be visualized to highlight diverse areas (Fig. 4). The highest geodiversity values occur in the Balaton Uplands, the Tapolca Basin, the Káli Basin, and the Bakony Mountains. Less diverse are the valley of Séd stream and the surroundings of the shores of Lake Balaton. The current visitor centres, important geosites and nature trails of the Geopark are mainly located in high geodiversity regions: 20 of them are in the 'red' cells, 9 are in the 'orange' cells, 2 are in yellow cells and 1 is in a green cell out of the 32 most important facilities.

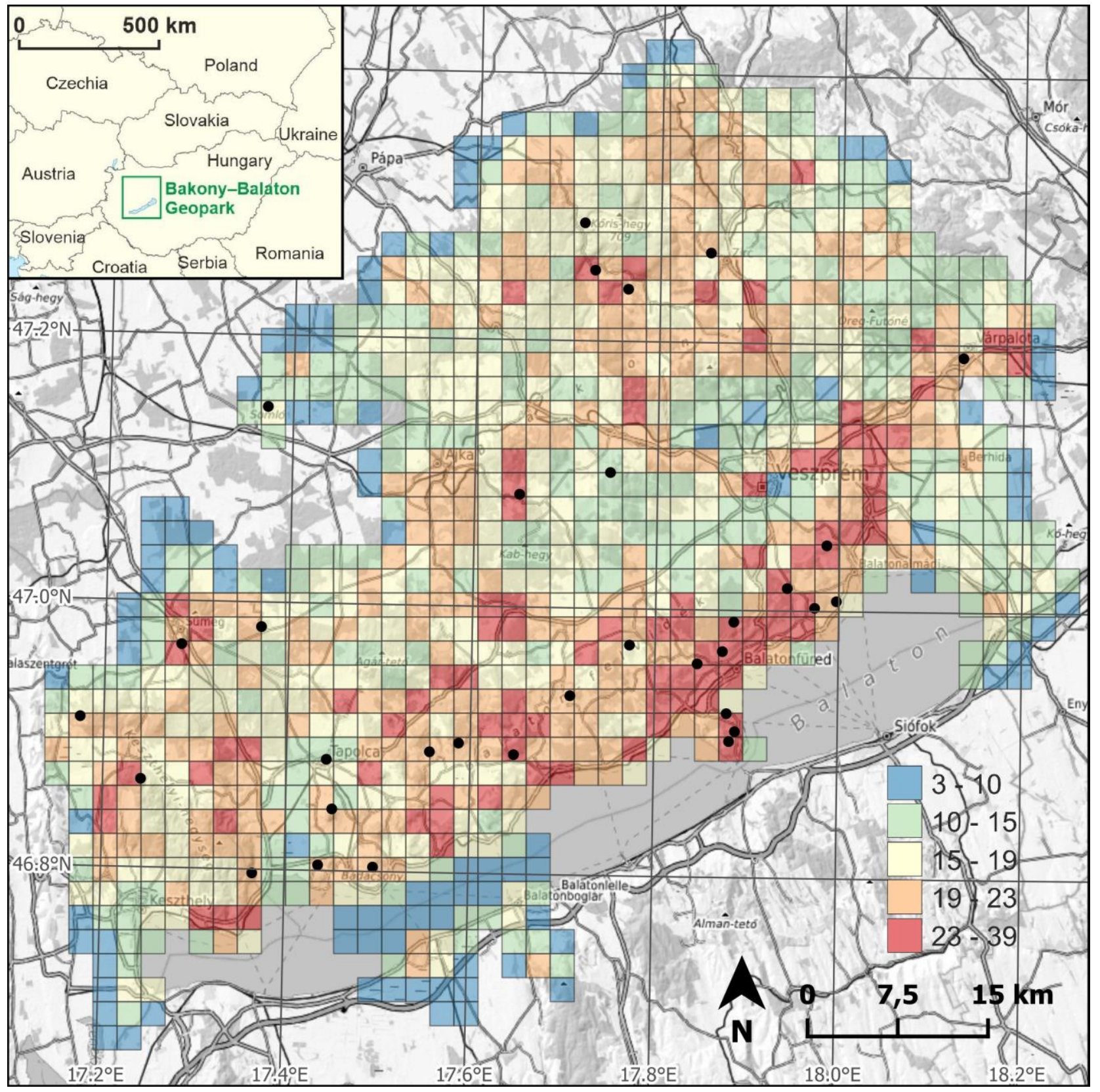

Figure 4. The geodiversity index map of the Bakony-Balaton UNESCO Global Geopark. The distribution of geotourism infrastructure (black dots) support that higher geodiversity usually means higher geotourism potential 


\section{Discussion and conclusion}

This paper aimed to present an easily reproducible workflow for the calculation and visualisation of the geodiversity index for a desired area.

Although in the case presented here most of the base data are freely accessible, the access to geological and soil datasets can be difficult in some countries. There are small-scale free data sources available for this purpose, but our experience is that these are not yet detailed enough to be used at a regional (i.e. geopark) scale. For example, we tried to use free but small-scale soil maps (e.g., Panagos et al. 2011), but the results of sub-index calculations lacked important details. The examination of visualisation solutions can be a future research topic: is the raster grid method the most suitable, or are there better methods. Although a derived interpolated continuous map is visually more satisfying, the raster-based method is more accurate as it contains original data.

This assessment also helped to identify that the geotourism infrastructure of the Geopark is closely linked to the high geodiversity. The identification of geosites is also based on this result: newly established geoparks can build up their geosite inventories, plan and develop tourism infrastructure based on geodiversity assessment.

\section{References}

ATK TAKI (Institute for Soil Sciences and Agricultural Chemistry) 2020: Az Agrotopográfiai adatbázisról. https://www.mta-

taki.hu/hu/osztalyok/kornyezetinformatikai-

osztaly/agrotopo. [Last access: 17 August 2021]

Bakony-Balaton Geopark (2020): Visitor sites, nature trails and guided geotours. http://geopark.hu/en/home/bakony-balaton-

geopark/geotourism. [Last access: August 18, 2021]

Budai, T., Császár, G., Csillag, G., Dudko, A., Koloszár, L. and Majoros, Gy. (1999): A Balaton-felvidék földtana - Magyarázó a Balaton-felvidék földtani térképéhez, 1: 50 000. Geological Institute of Hungary, Budapest.

Budai, T., Futó, J., Vers, J., Schleicher, V., and Korbély, B. (2021). Bakony-Balaton UNESCO Globális Geopark. In: Tardy, J. (ed.): Geoparkok Magyarországon. Hungarian Society of Natural Sciences, Budapest, Hungary. ISBN 9786155015588.

Császár, G. (1997). Basic lithostratigraphic units of Hungary. Charts and short descriptions, Geological Institute of Hungary. Budapest.

De Paula Silva, J.; Rodrigues, C. and Pereira, D.I. (2015). Mapping and Analysis of Geodiversity Indices in the Xingu River Basin, Amazonia, Brazil. Geoheritage, 7:337-350.

Gray, M. (2004). Valuing and Conserving Abiotic Nature; John Wiley \& Sons, Ltd., Hoboken, NJ, USA, ISBN 0470848952.

Gray, M. (2008). Geodiversity: The origin and evolution of a paradigm. Geol. Soc. Lond. Spec. Publ. 300, pp. 3136.
Gray, M. (2018). Geodiversity: The Backbone of Geoheritage and Geoconservation; Elsevier Inc., Amsterdam, The Netherlands, ISBN 9780128095423.

Gyalog, L. ed. (1996). A földtani térképek jelkulcsa és a rétegtani egységek rövid leírása. Geological Institute of Hungary. Budapest.

Gyalog, L. ed. (2005). Magyarázó Magyarország fedett földtani térképéhez (az egységek rövid leírása). Geological Institute of Hungary. Budapest.

Gyalog, L. and Síkhegyi, F. eds. (2005). Geological map of Hungary $(1: 100$ 000). Online: https://map.mbfsz.gov.hu/fdt100/. Geological Institute of Hungary, Budapest.

Jasiewicz, J. and Stepinski, T. (2013). Geomorphons - a pattern recognition approach to classification and mapping of landforms. Geomorphology, vol. 182, pp. 147-156.

DOI: https://doi.org/10.1016/j.geomorph.2012.11.005.

Jenks, G.F. (1967). The Data Model Concept in Statistical Mapping. International Yearbook of Cartography, 7:186190.

Kozłowski, S. (2004). Geodiversity. The concept and scope of geodiversity. Przeglad Geologiczny. 52:833837.

Minelli, A. and Bonato, L. (2012). Diversity of Life. John Wiley \& Sons, Ltd.: Chichester, UK, pp. 1-7; ISBN 9780470015902.

Ösi, A. (2004). The first dinosaur remains from the Upper Cretaceous of Hungary (Csehbánya Formation, Bakony Mts). Geobios, 37:749-753.

Panagos, P., Jones, A., Bosco, C., Senthil Kumar P.S. (2011). European digital archive on soil maps (EuDASM): preserving important soil data for public free access. International Journal of Digital Earth, 4 (5), pp. 434-443. DOI:10.1080/17538947.2011.596580

Pereira, D.I., Pereira, P., Brilha, J. and Santos, L. (2013). Geodiversity assessment of Paraná State (Brazil): An innovative approach. Environmental Management, 52:541-552.

Serrano, E. and Ruiz-Flaño, P. (2007). Geodiversity: A theoretical and applied concept. Geographica Helvetica, 62:140-147.

Strahler, A.N. (1957). Quantitative analysis of watershed geomorphology. Eos, 38(6):913-920. DOI: https://doi.org/10.1029/TR038i006p00913.

Yamazaki, D., Ikeshima, D., Tawatari, R., Yamaguchi, T., O'Loughlin, F., Neal, J.C., Sampson, C.C., Kanae, S. and Bates, P.D. (2017). A high accuracy map of global terrain elevations. Geophysical Research Letters, vol.44, pp.5844-5853, $2017 \quad$ DOI: https://doi.org/10.1002/2017GL072874. 